\title{
NUTRITION STATUS OF HIGH PERFORMANCE ROWERS, CANOEISTS AND KAYAKERS
}

\author{
Marius Baranauskas ${ }^{1,3}$, Linas Tubelis ${ }^{2,3}$, Rimantas Stukas $^{1}$, Edmundas Švedas $^{4}$, \\ Laimutè Samsoniené ${ }^{5}$, Diana Karanauskiené $\dot{ }^{6}$ \\ Vilnius University Faculty of Medicine Public Health Institute', Vilnius, Lithuania \\ Vilnius University of Educational Sciences'2, Vilnius, Lithuania \\ Lithuanian Olympic Sport Centre ${ }^{3}$, Vilnius, Lihuania \\ Lithuanian Sports Medicine Centre ${ }^{4}$, Vilnius, Lihuania \\ Vilnius University Sports and Health Centre ${ }^{5}$,Vilnius, Lithuania \\ Lithuanian Sports University ${ }^{6}$, Kaunas, Lithuania
}

\begin{abstract}
Research background and hypothesis. Rowing and canoeing-kayaking are some of the leading sports in Lithuania, and athletes have achieved victories in European and world championships. In order to effectively manage the preparation of Lithuanian elite rowers, canoeists and kayakers, research in their nutrition status is important, relevant and necessary. Hypothesis: dietary intake of rowers and canoeists-kayakers comply with nutrition requirements.

Research aim was to assess nutrition status, physical development and the interactions between them for Lithuanian Olympic team rowers, canoeists and kayakers.

Research methods. Research on the nutrition status and supplementation was carried out in the preparatory competition period in 2012. The sample included $18.2 \pm 2.3$-year-old rowers $(\mathrm{n}=24)$ and $21.5 \pm 5.2$-year-old canoeists-kayakers $(\mathrm{n}=12)$. Body composition analysis and physical development of athletes was performed using multi-frequency bioelectrical impedance analysis (BIA) method.

Research results. Regardless of gender, MFMI of kayakers-canoeists and rowers was only average. Athletes' dietary energy intake (EI) does not fully cover the energy expenditure, the diet lacks carbohydrates, dietary fibres, omega- 3 fatty acids, vitamin D, and there is too much fat, saturated fatty acids and cholesterol. $92 \%$ of athletes take supplements. Most often athletes' dietary supplementation includes carbohydrates (73.9\%), amino acids (73.9\%), minerals (73.9\%), vitamins (65.2\%), and multivitamins (65.2\%).

Discussion and conclusions. Nutrition status and physical development of Lithuanian elite kayakers-canoeists and rowers does not meet the requirements of nutrition. Diets of high performance kayakers-canoeists and rowers must be optimized, adjusted and individualized.
\end{abstract}

Keywords: rowers, canoeists and kayakers, high sports performance, athlete nutrition.

\section{INTRODUCTION}

$\mathrm{P}$ roper and balanced diet leads to athletes' improved health and physical working capacity indicators, helps to reduce violations of the body resulting from the intense and long-lasting physical loads. Sports nutrition characteristics depend on the physical load, workout mode leading to completely different needs of athlete's body for nutrients compared to the population of non-athletes. Rowing sport in Lithuania has very deep and long-standing traditions; rowers have achieved major victories. Today rowing is one of the leading Lithuanian sports and athletes in this sport win awards at European and world championships, so it is very 
important to improve planning and management of the preparation of elite rowers as well as highlight not only the main features of rowers who have close links with the main sports results of the covered distance, but also their nutrition characteristics. In other countries and in Lithuania nutrition of elite rowers, canoeists and kayakers has not been much researched. In order to effectively manage the preparation of Lithuanian elite rowers, canoeists and kayakers, research in their nutrition status is important, relevant and necessary. The aim of the present research was to assess nutrition status, physical development and the interactions between them for Lithuanian Olympic team rowers, canoeists and kayakers.

\section{RESEARCH METHODS}

Participants. Research on the nutrition status was carried out in the preparatory competition period in 2012. The sample included $18.2 \pm 2.3$-year-old rowers $(\mathrm{n}=24)$ and $21.5 \pm 5.2$-year-old canoeists-kayakers $(n=12)$. The subjects trained six times a week, $175.3 \pm 45.9 \mathrm{~min}$ a day. Their sports experience was $7.1 \pm 4.1$ years. They were athletes included in the approved lists of perspective candidates for the Lithuanian Olympic team, preparing for the Olympic Games (Table 1).

Anthropometric measures. Athletes' height was measured applying electronic scales at the Lithuanian Sport Medicine Centre. Body composition analysis of athletes was performed at the Lithuanian Olympic Sports Centre using Body Composition Analyser X-SCAN using multifrequency bioelectrical impedance analysis (BIA) method (American College of Sports Medicine, 2009) applied in research with athletes. We also established athletes' body weight (BW) (kg), fatfree mass (FFM) (kg and \%), protein mass (PM)
( $\mathrm{kg}$ and \%), body minerals (M) ( $\mathrm{kg}$ and \%) and body fat (BF) ( $\mathrm{kg}$ and \%), as well as body mass index (BMI) (The World Health Report, 2002) and muscle and fat mass index (MFMI) (Skernevičius et al., 2004).

Physical activity level. To estimate total energy expenditure and basal metabolic rate we used Harris-Benedict equation (Haris, Benedict, 1919). To estimate exercise energy expenditure we used metabolic equivalents records over a 24 -hour period (Ainsworth et al., 2011). 24-hour records of physical activity were collected on the same day participants recorded their dietary intakes to estimate physical activity level during a period of active training.

Dietary intake. Nutrition status of athletes in the Lithuanian Olympic Team was assessed using the food recall method. Respondents were interviewed by a trained interviewer in the course of direct interviews at the Lithuanian Olympic Sports Centre. We recorded the data for each athlete's consumed food and dishes. Dietary recall was investigated using special Atlas of Foodstuffs and Dishes Sizes where portions of different foods and meals evaluated in grams were presented in order to record all consumed food and dishes as well as their amounts. In addition, food supplements (carbohydrates, amino acids, vitamins, minerals, multivitamin, omega-FA (fatty acids), L-carnitine, herbal, caffeine, creatine) as well as their usage peculiarities were assessed, but their chemical composition was not included in the chemical composition of the diet.

Inaccordancewith thetablesoffoodcomposition, we calculated the chemical composition of athletes' diet (Sučilienè, Abaravičius, 2002). We estimated athletes' carbohydrate, protein, dietary fat, phosphorus, calcium, potassium and magnesium intakes. Macronutrient intake was assessed

\begin{tabular}{|c|c|c|c|}
\hline \multirow{2}{*}{ Age and sports experience } & $\begin{array}{l}\text { Canoeists and kayakers } \\
\qquad(\mathrm{n}=12)\end{array}$ & $\begin{array}{l}\text { Rowers } \\
(n=24)\end{array}$ & $\begin{array}{c}\text { Total } \\
(n=36)\end{array}$ \\
\hline & \multicolumn{3}{|c|}{ Mean \pm SD } \\
\hline Sports experience, yr & $5.7 \pm 2.7$ & $12.8 \pm 0.4$ & $7.1 \pm 4.1$ \\
\hline Workouts per week, no & $5.8 \pm 0.4$ & 6.0 & $5.8 \pm 0.4$ \\
\hline Workouts per day, no & $1.6 \pm 0.5$ & $1.8 \pm 0.4$ & $1.6 \pm 0.5$ \\
\hline Average training time per day, min & $116.3 \pm 23.8$ & $104.0 \pm 19.4$ & $113.8 \pm 23.2$ \\
\hline Total training time per day, min & $173.8 \pm 42.4$ & $178.3 \pm 54.1$ & $175.34 \pm 45.9$ \\
\hline Age, yr & $18.2 \pm 2.3$ & $21.5 \pm 5.2$ & $19.1 \pm 3.8$ \\
\hline
\end{tabular}

Table 1. Age and sports experience of Lithuanian Olympic team canoeists, kayakers and rowers 
according to the recommendations provided in research literature (American College of Sports Medicine, 2009; Burke, 2010; Kreider et al., 2010). Compliance of micronutrient intake with RDI was assessed referring to recommended daily intake norms approved in Lithuania (Rekomenduojamos paros maistiniu medžiagu ir energijos normos, 1999). As RDI of vitamins and minerals depends on age and gender, the uptake of these materials is given as a percentage of RDI (intake/RDI x 100).

Data analysis. Statistical data analysis was carried out using the SPSS (Statistical Package for Social Sciences) v. 15.0. Data analysis was performed using conventional methods of descriptive statistics: calculation of arithmetic means, standard deviations (SD). Student's t-test was used for the comparison of means between two independent groups of respondents. Categorical data analysis was performed using Fisher's exact test. The relationship between variables was assessed calculating statistical significance and Pearson's correlation coefficient. Hypothesis was verified using the level of significance of $\alpha=0.05$. The significance level was set at $\mathrm{p}<0.05$.

\section{RESEARCH RESULTS}

Physical development. The analysis of the physical condition of the Lithuanian Olympic team rowers, canoeists and kayakers (Table 2) showed that BW, LBM, MM, FM, PM, M and MFMI of male and female athletes in different branches of sport did not differ. The only established difference was in athletes' BMI. Excessive BMI indicating overweight $\left(25.8 \pm 1.9 \mathrm{~kg} / \mathrm{m}^{2}\right)$ was typical of male canoeists and kayakers. BMI of male rowers $\left(23.9 \pm 1.9 \mathrm{~kg} / \mathrm{m}^{2}\right)$ was significantly lower than the one of male canoeists and kayakers $(p=0.032)$, and it was regarded as normal. Women athletes' BMI in both sports was within the normal range.

MFMI was assessed in order to objectively evaluate if the physical condition of the athletes met the requirements for high performance athletes. It was found that MFMI of male canoeists-kayakers and rowers, respectively equal to $4.3 \pm 1.4$ and $3.9 \pm 1.0$, did not differ $(\mathrm{p}=0.393)$, and was regarded as average (average MFMI for men is 3.4-4.69). Meanwhile, MFMI of female athletes in kayakcanoe and rowing sport, respectively $2.9 \pm 0.5$ and

Table 2. Anthropometric data of Lithuanian Olympic team canoeists, kayakers and rowers

\begin{tabular}{|c|c|c|c|c|c|c|c|c|}
\hline \multirow{3}{*}{$\begin{array}{c}\text { Anthropometric } \\
\text { data }\end{array}$} & \multicolumn{2}{|c|}{ Canoeists and kayakers } & \multicolumn{2}{|c|}{ Rowers } & \multirow{2}{*}{\multicolumn{2}{|c|}{ t-test ${ }^{1 / 3}$}} & \multirow{2}{*}{\multicolumn{2}{|c|}{ t-test $t^{2 / 4}$}} \\
\hline & $\operatorname{Male}^{1}(n=7)$ & $\operatorname{Female}^{2}(n=5)$ & Male $^{3}(n=21)$ & Female $^{4}(n=3)$ & & & & \\
\hline & \multicolumn{4}{|c|}{ Mean \pm SD } & $\mathbf{t}$ & $\mathbf{p}$ & $\mathbf{t}$ & $\mathbf{p}$ \\
\hline Height, cm & $185.6 \pm 6.0$ & $169.1 \pm 1.9$ & $191.8 \pm 6.1$ & $176.8 \pm 7.3$ & 2.345 & 0.027 & 2.354 & 0.057 \\
\hline $\mathrm{BW}, \mathrm{kg}$ & $88.7 \pm 7.8$ & $65.0 \pm 3.2$ & $88.1 \pm 8.8$ & $71.4 \pm 7.2$ & -0.189 & 0.852 & 1.779 & 0.126 \\
\hline LBM, kg & $72.1 \pm 5.7$ & $49.0 \pm 0.7$ & $70.4 \pm 5.0$ & $54.6 \pm 4.1$ & -0.734 & 0.470 & 2.365 & 0.138 \\
\hline LBM, \% & $81.4 \pm 4.9$ & $75.5 \pm 3.2$ & $80.0 \pm 3.4$ & $76.7 \pm 4.0$ & -0.842 & 0.408 & 0.455 & 0.665 \\
\hline MM, kg & $66.9 \pm 5.4$ & $45.2 \pm 0.6$ & $65.3 \pm 4.5$ & $50.4 \pm 3.7$ & -0.782 & 0.441 & 2.492 & 0.132 \\
\hline MM, \% & $75.5 \pm 4.9$ & $69.7 \pm 3.2$ & $74.4 \pm 3.6$ & $70.9 \pm 3.9$ & -0.643 & 0.526 & 0.463 & 0.66 \\
\hline $\mathrm{FM}, \mathrm{kg}$ & $16.7 \pm 5.2$ & $16.0 \pm 2.9$ & $17.7 \pm 4.7$ & $16.8 \pm 4.3$ & 0.457 & 0.652 & 0.319 & 0.760 \\
\hline FM, \% & $18.6 \pm 4.9$ & $24.5 \pm 3.2$ & $19.8 \pm 3.6$ & $23.3 \pm 4.0$ & 0.646 & 0.524 & -0.455 & 0.665 \\
\hline PM, kg & $15.0 \pm 1.3$ & $10.0 \pm 0.1$ & $14.6 \pm 1.0$ & $11.2 \pm 0.8$ & -0.919 & 0.366 & 2.618 & 0.115 \\
\hline PM, \% & $17.0 \pm 1.3$ & $15.4 \pm 0.9$ & $16.6 \pm 1.0$ & $15.7 \pm 1.1$ & -0.692 & 0.495 & 0.458 & 0.663 \\
\hline $\mathrm{M}, \mathrm{kg}$ & $5.1 \pm 0.4$ & $3.8 \pm 0.2$ & $5.1 \pm 0.5$ & $4.1 \pm 0.4$ & -0.158 & 0.876 & 1.849 & 0.114 \\
\hline $\mathrm{M}, \%$ & $5.8 \pm 0.1$ & $5.8 \pm 0.1$ & $5.8 \pm 0.1$ & $5.8 \pm 0.1$ & -0.168 & 0.868 & 0.457 & 0.663 \\
\hline BMI, $\mathrm{kg} / \mathrm{m}^{2}$ & $25.8 \pm 1.9$ & $22.7 \pm 1.6$ & $23.9 \pm 1.9$ & $22.8 \pm 2.3$ & -2.264 & 0.032 & 0.473 & 0.947 \\
\hline MFMI & $4.3 \pm 1.4$ & $2.9 \pm 0.5$ & $3.9 \pm 1.0$ & $3.1 \pm 0.7$ & -0.869 & 0.393 & 0.492 & 0.640 \\
\hline
\end{tabular}

Note. Values are expressed as mean \pm SD; BW - Body Weight; LBM - Lean Body Mass; MM - Muscle Mass; FM - Fat Mass; PM - Protein Mass; M - Body Minerals; BMI - Body Mass Index; MFMI - Muscle and Fat Mass Index.

Significant differences set by independent samples Student's t-test among groups: ${ }^{1}-$ Group $1,{ }^{2}$ - Group $2,{ }^{3}$ - Group $3,{ }^{4}-$ Group 4 . 
$3.1 \pm 0.7$, did not differ $(\mathrm{p}=0.640)$ and also was medium (average MFMI of women is 2.9-3.99).

Evaluation of athletes' fat mass revealed the differences by gender. Irrespective of the sports branch, women athletes' fat mass was seen as optimal, and for male athletes it was too big and seen as only acceptable (Table 2).

The evaluation of the relationship of BMI with the PM and the FM for male and female athletes showed that higher body mass of men and higher BMI were related to both higher muscle mass $(r=0.634, p<0.001)$ and higher fat mass $(r=0.559$, $p=0.002)$. Meanwhile, for women athletes the higher BMI had a strong connection to the fat mass $(r=0.961, p<0.001)$, but there were no links with muscle mass $(\mathrm{r}=0.131, \mathrm{p}=0.131)$ (Figure 1). It can be concluded that men athletes have a tendency to increase the total body mass at the expense of muscle and fat mass and their MFMI is below high levels only when they have excessive fat mass. Meanwhile, for women athletes, the average MFMI is determined by low muscle mass.

Dietary intake. The analysis of athletes' food rations showed that regardless of the branch of sport and gender, kayakers-canoeists and rowers do not cover their daily estimated energy expenditure with the food they eat (Table 3).

Table 4 gives the results of athletes' food recall. The evaluation of athletes' consumed macronutrient amounts revealed that fat intake exceeded the recommended norms (fat supply energy value ranged from 35 to $42 \%$ ) among all the tested athletes. The analysis of the fat qualitative value of athletes' food rations showed that athletes

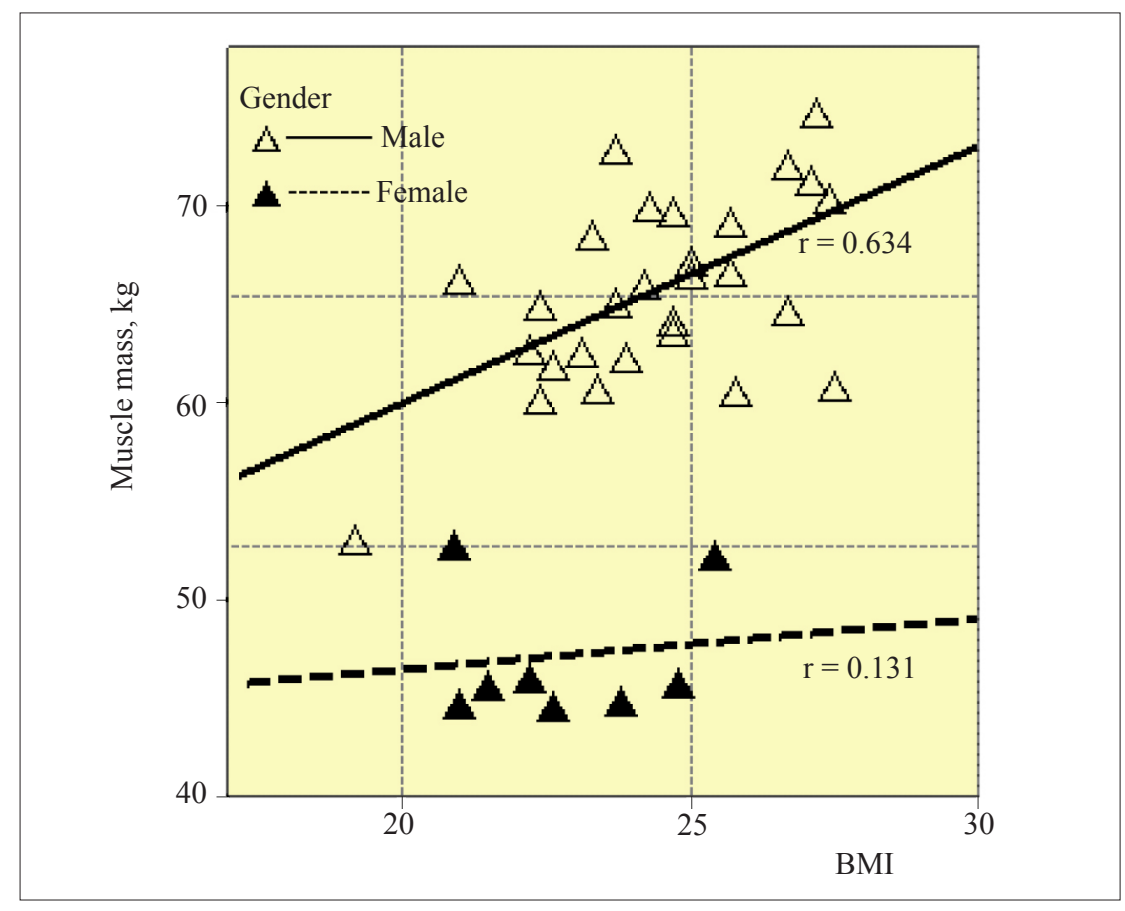

\begin{tabular}{|l|c|c|c|c|}
\hline \multirow{2}{*}{$\begin{array}{c}\text { Daily energy } \\
\text { intake vs. energy } \\
\text { expenditure }\end{array}$} & \multicolumn{2}{|c|}{ Canoeists and kayakers } & \multicolumn{2}{c|}{ Rowers } \\
\cline { 2 - 5 } & Male (n=7) & Female (n= 5) & Male (n= 21) & Female (n= 3) \\
\cline { 2 - 5 } & \multicolumn{4}{|c|}{ Mean \pm SD } \\
\hline EER, kcal & $5473.2 \pm 1005.6$ & $3771.5 \pm 422.0$ & $5303.1 \pm 638.6$ & $4258.0 \pm 338.9$ \\
\hline EER, kcal BW & $61.6 \pm 9.1$ & $58.0 \pm 5.4$ & $60.4 \pm 6.5$ & $59.8 \pm 3.2$ \\
\hline EI, kcal & $3710.5 \pm 680.2$ & $2296.4 \pm 132.9$ & $3952.2 \pm 945.7$ & $2999.6 \pm 605.6$ \\
\hline EI, kcal/kg BW & $42.0 \pm 8.4$ & $35.4 \pm 3.1$ & $45.2 \pm 11.1$ & $42.6 \pm 10.9$ \\
\hline$\%$ EER & $68.7 \pm 12.5$ & $61.7 \pm 10.4$ & $75.5 \pm 19.8$ & $70.8 \pm 14.9$ \\
\hline
\end{tabular}

Figure 1. Correlation of BMI with muscle mass (by gender)

Note. BMI - Body Mass Index.

Table 3. Energy intake of Lithuanian Olympic team canoeists, kayakers and rowers

Note. Values are expressed as mean $\pm \mathrm{SD}$; EI - Energy Intake; EER - Estimated Energy Requirement; BW - Body Weight; \% EER - Ratio of EER and EEI. 
Table 4. Dietary intake of Lithuanian Olympic team canoeists, kayakers and rowers

\begin{tabular}{|c|c|c|c|c|c|c|}
\hline \multirow{3}{*}{ Nutrition profile } & \multicolumn{3}{|c|}{ Canoeists and kayakers } & \multicolumn{3}{|c|}{ Rowers } \\
\hline & $\begin{array}{c}\text { Male } \\
(\mathrm{n}=7)\end{array}$ & $\begin{array}{c}\text { Female } \\
(\mathrm{n}=5)\end{array}$ & \multirow{2}{*}{ Recommended } & $\begin{array}{c}\text { Male } \\
(\mathrm{n}=\mathbf{2 1})\end{array}$ & $\begin{array}{c}\text { Female } \\
(\mathrm{n}=3)\end{array}$ & \multirow{2}{*}{ Recommended } \\
\hline & \multicolumn{2}{|c|}{ Mean \pm SD } & & \multicolumn{2}{|c|}{ Mean \pm SD } & \\
\hline $\mathrm{CHO}, \mathrm{g} / \mathrm{kg} \mathrm{BW}$ & $4.0 \pm 1.2$ & $4.4 \pm 0.5$ & $7-10$ & $4.6 \pm 1.3$ & $4.6 \pm 0.8$ & $7-10$ \\
\hline $\mathrm{CHO}, \%$ & $38.6 \pm 11.3$ & $49.4 \pm 2.4$ & $>55$ & $40.9 \pm 10.6$ & $44.1 \pm 5.7$ & $55-70$ \\
\hline Dietary fibre, $\mathrm{g} / 1000 \mathrm{kcal}$ & $8.5 \pm 2.3$ & $8.7 \pm 0.8$ & 14 & $9.9 \pm 3.3$ & $8.6 \pm 3.6$ & 14 \\
\hline PRO, g/kg BW & $2.0 \pm 0.9$ & $1.4 \pm 0.1$ & $1.6-1.8$ & $1.6 \pm 0.4$ & $1.4 \pm 0.2$ & $1.4-1.6$ \\
\hline EEA, mg BW & $761.4 \pm 373.2$ & $513.8 \pm 47.1$ & $491-545$ & $570.8 \pm 165.1$ & $505.9 \pm 54.8$ & $436-491$ \\
\hline Val, mg BW & $107.2 \pm 48.6$ & $75.1 \pm 6.0$ & $63-71$ & $84.9 \pm 24.5$ & $74.2 \pm 8.5$ & $55-63$ \\
\hline Leu, mg BW & $159.0 \pm 75.4$ & $109.7 \pm 11.3$ & $95-106$ & $120.0 \pm 35.3$ & $109.1 \pm 12.5$ & $83-95$ \\
\hline Izoleu, mg BW & $96.6 \pm 48.2$ & $63.4 \pm 6.4$ & $48-55$ & $72.3 \pm 20.8$ & $62.6 \pm 7.5$ & $42-48$ \\
\hline $\mathrm{BCAA}, \mathrm{mg}$ & $362.7 \pm 172.2$ & $248.3 \pm 23.6$ & $206-232$ & $277.2 \pm 80.3$ & $246.0 \pm 28.0$ & $180-206$ \\
\hline FAT, \% & $42.5 \pm 13.3$ & $34.6 \pm 1.7$ & $20-30$ & $45.1 \pm 10.2$ & $42.3 \pm 7.3$ & $20-30$ \\
\hline SFA, $\%$ & $12.1 \pm 4.1$ & $12.0 \pm 1.0$ & $<10 \%$ & $15.5 \pm 4.9$ & $12.9 \pm 0.8$ & $<10 \%$ \\
\hline PUFA, $\%$ & $10.9 \pm 5.5$ & $6.9 \pm 1.1$ & $6-10 \%$ & $6.6 \pm 2.7$ & $6.4 \pm 1.1$ & $6-10 \%$ \\
\hline Omega-3 FA, $\%$ & $0.6 \pm 0.4$ & $0.3 \pm 0.1$ & $1-2 \%$ & $0.4 \pm 0.1$ & $0.4 \pm 0.2$ & $1-2 \%$ \\
\hline Omega-6 FA, \% & $9.9 \pm 5.2$ & $6.3 \pm 1.0$ & $6-10 \%$ & $6.0 \pm 2.5$ & $5.7 \pm 0.9$ & $6-10 \%$ \\
\hline Cholesterol, mg & $1155.7 \pm 468.4$ & $620.0 \pm 155.6$ & $£ 500$ & $1083 \pm 494.6$ & $780.7 \pm 295.8$ & $£ 500$ \\
\hline
\end{tabular}

Note. Values are expressed as mean \pm SD; LBM - Lean Body Mass; BW - Body Weight; CHO - carbohydrate; PRO - protein; EAA - Essential Amino Acids; Val - Valine; Izole - Izoleucine; Leu - Leucine; BCAA - Branch Chain Amino Acids; FAT - Fat; FA - Fatty Acids; SFA - Saturated Fatty Acids; PUFA - Polyunsaturated Fatty Acids.

consumed more than recommended saturated FA, cholesterol and not enough omega-3 FA. Following the recommendations athletes consumed polyunsaturated FA and omega-6 FA.

During long-term and intense physical loads, aerobic reactions in athlete's body become important when the energy is produced from carbohydrates. For this reason, elite athletes have to intake the recommended amount of carbohydrates with food equal to $7-10 \mathrm{~kg} /$ body weight. Our research results showed that regardless of gender, rowers as well as canoeists-kayakers reported low dietary intake of carbohydrates, far below the recommended amounts of carbohydrates. This was confirmed by male and female kayakers-canoeists' carbohydrate content which was respectively equal to $4.0 \pm 1.2 \mathrm{~g} / \mathrm{kg}$ body weight and $4.4 \pm 0.5 \mathrm{~g} / \mathrm{kg}$ body weight. Similar quantities of carbohydrates were consumed by rowers. Male and female rowers' diets included carbohydrates amounting to $4.6 \pm 1.3 \mathrm{~g} / \mathrm{kg}$ body weight and $4.6 \pm 0.8 \mathrm{~g} / \mathrm{kg}$ body weight (Table 4).
Dietary fibre which does not provide energy is also important in athlete nutrition. Recommended dietary fibre intake is $14 \mathrm{~g}$ per $1000 \mathrm{kcal}$. After analysing the food recall records of athletes we found that the athletes' average intake of dietary fibre was less than $9 \mathrm{~g} / 1000 \mathrm{kcal}$ and it was below the recommended norm (Table 4).

In order to maintain a positive protein balance in the body, athletes are recommended to consume a sufficient amount of proteins. It was found that the average consumption of proteins among men and women kayakers-canoeists was respectively equal to $2.0 \pm 0.9 \mathrm{~g} / \mathrm{kg}$ body weight and $1.4 \pm 0.1 \mathrm{~g} / \mathrm{kg}$ body weight, which does not meet the guidelines: men consumed too much and women too little proteins. Meanwhile, rowers irrespective of gender consumed proteins more rationally. Consumption of proteins for rowers, both men and women, was respectively $1.6 \pm 0.4 \mathrm{~g} / \mathrm{kg}$ body weight and $1.4 \pm 0.2 \mathrm{~g} / \mathrm{kg}$ body weight, which is the recommended amount. Additional assessment of the athletes' qualitative intake of proteins showed that regardless of the branch of sport and gender, 
the tested athletes consumed essential amino acids (EEA), including branch chain amino acids (BCAA) (valine, leucine and isoleucine) in excess of the recommended quantities (Table 4).

Athletes' body supply of micronutrient status is indicated in Figures 2 and 3 . Athletes consumed more of almost all of the vitamins and minerals than it was recommended. However, regardless of the sport, athletes consumed insufficient amounts of vitamin D. Kayakers-canoeists' diets included $4.5 \pm 2.3 \mathrm{mg}$ of vitamin D, rowers' diets $-3.4 \pm 2.3 \mathrm{mg}$, which made $47-69 \%$ of RDI. Moreover, kayakerscanoeists' diets lacked folic acid and manganese. Female athletes consumed insufficient amounts of folic acid $(219.8 \pm 29.4 \mu \mathrm{g} / 94 \%$ of RDI), and male athletes - manganese $(4.2 \pm 1.5 \mathrm{mg} / 84 \%$ of RDI).

Food supplementation. Dietary supplements were reported to have been used by $92 \%$ of the Lithuanian Olympic team rowers and kayakerscanoeists. Even $60 \%$ of the athletes took food supplements 7-12 months per year, and 32\% - 1-6 months per year. Most often athletes used food supplements containing carbohydrates (73.9\%), amino acids (73.9\%), minerals $(73.9 \%)$, vitamins (65.2\%), and multivitamins (65.2\%). Fewer (35.0\%) athletes took omega fatty acids, creatine and herbal supplements. Least often athletes used L-carnitine (13.0\%) and caffeine (8.7\%) supplements. Analysing the use of food supplements in the aspect of the branch sport we found that the kayakers-canoeists compared with rowers more often used creatine and caffeine $(\mathrm{p}=0.002, \mathrm{p}=0.040)$. Creatine and caffeine were used by respectively 100 and $40 \%$ of kayakers and canoeists. Meanwhile, the rowers did not consume caffeine at all, and they made only $16.7 \%$ of creatine users. Moreover, we found that the use of dietary supplements among athletes for men and women was almost identical, except for the fact that women athletes $(100 \%)$ more often than men athletes $(25 \%)$ used herbal supplements $(\mathrm{p}=0.032)$.

Links between dietary intake and body composition. The analysis of the links between dietary intake and athletes' body composition showed that higher fat mass was not related to athletes' higher fat mass $(\mathrm{r}=0.164, \mathrm{p}=0.339)$ because the energy intake from food of the tested athletes was less than the energy expenditure.

Muscle mass of both male kayakers-canoeists and rowers was well-developed. Meanwhile, the women athletes' muscle mass was too low and was associated with poorer physical condition compared to male athletes. The assessment of links between the dietary intake and the muscle mass revealed that the increased muscle mass of the Lithuanian elite kayakers-canoeists and rowers was developed

Figure 2. Vitamin and mineral intake of athletes (by sports)

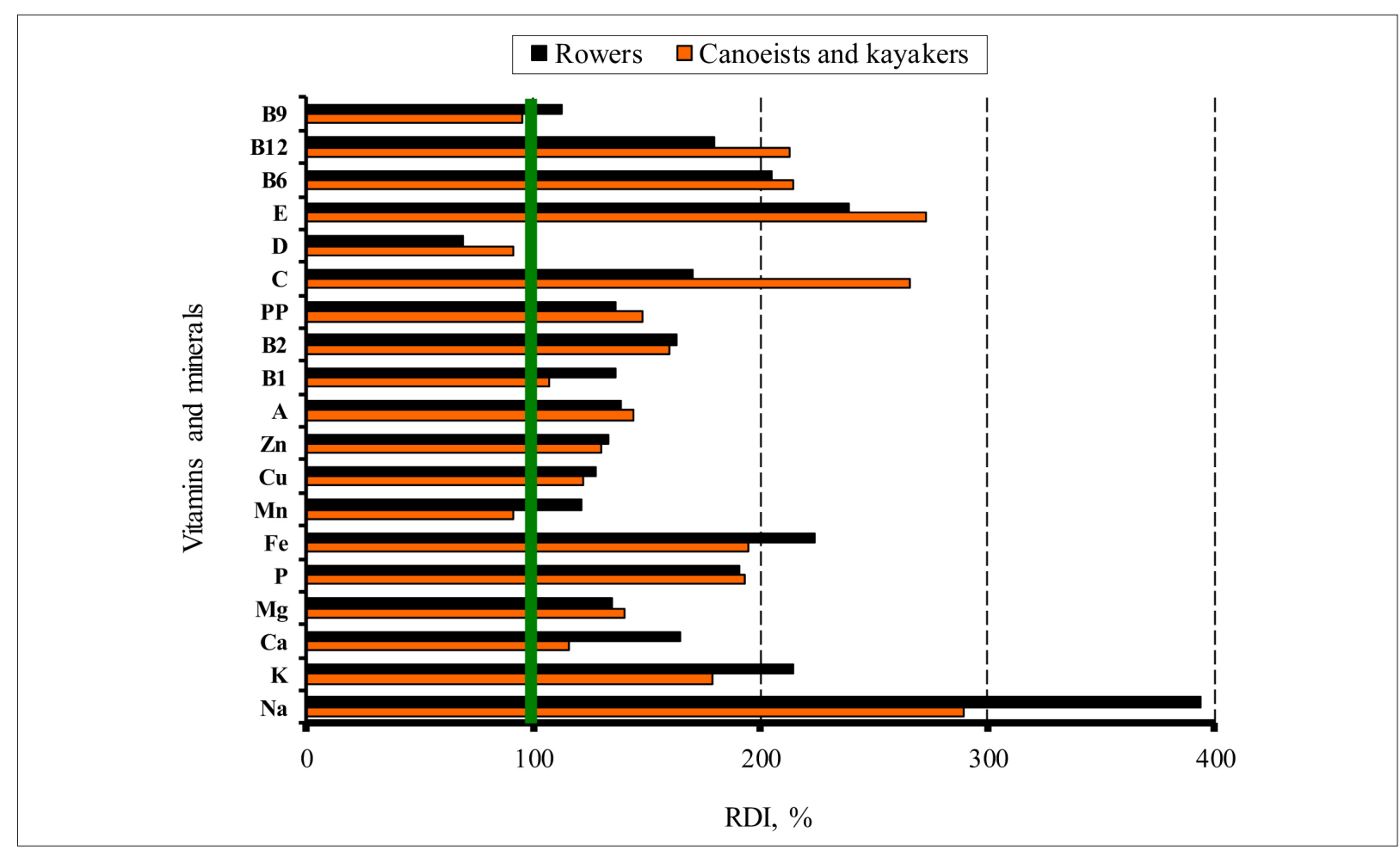

Note. Values are expressed as mean; RDI - Recommended Daily Intake; Zn -Zinc; Cu = Cooper; Mn - Manganese; Fe - Iron; P - Phosphorus; $\mathrm{Mg}$ - Magnesium; Ca - Calcium; K - Potassium; $\mathrm{Na}$ - Sodium. 
by using food containing sufficient energy value, high-fat, high-protein, EAA, B group vitamins $\left(\mathrm{B}_{1}\right.$, $\mathrm{B}_{6}, \mathrm{~B}_{9}$ ) and magnesium. This was confirmed by a statistically significant relationship between higher muscle mass of athletes and the higher energy intake from food ( $\mathrm{r}=0.505, \mathrm{p}=0.002)$, higher intake of fat $(r=0.547, p=0.001)$, protein $(r=0.361, p=0.030)$,
EAA $(r=0.338, p=0.044)$, BCAA $(r=0.337$, $\mathrm{p}=0.044)$, threonine $(\mathrm{r}=0.370, \mathrm{p}=0.026)$, tryptophan $(\mathrm{r}=0.436, \mathrm{p}=0.008)$, phenylalanine $(\mathrm{r}=0.345 \mathrm{p}=0.040)$, arginine $(\mathrm{r}=0.385, \mathrm{p}=0.020)$, vitamin $B_{1}(r=0.348, p=0.038), B_{6}(r=0.470$, $p=0.004), B_{9}(r=0.331, p=0.048)$ and magnesium $(r=0.336, p=0.050)($ Figure 4).

Figure 3. Vitamin and mineral intake of athletes (by gender)

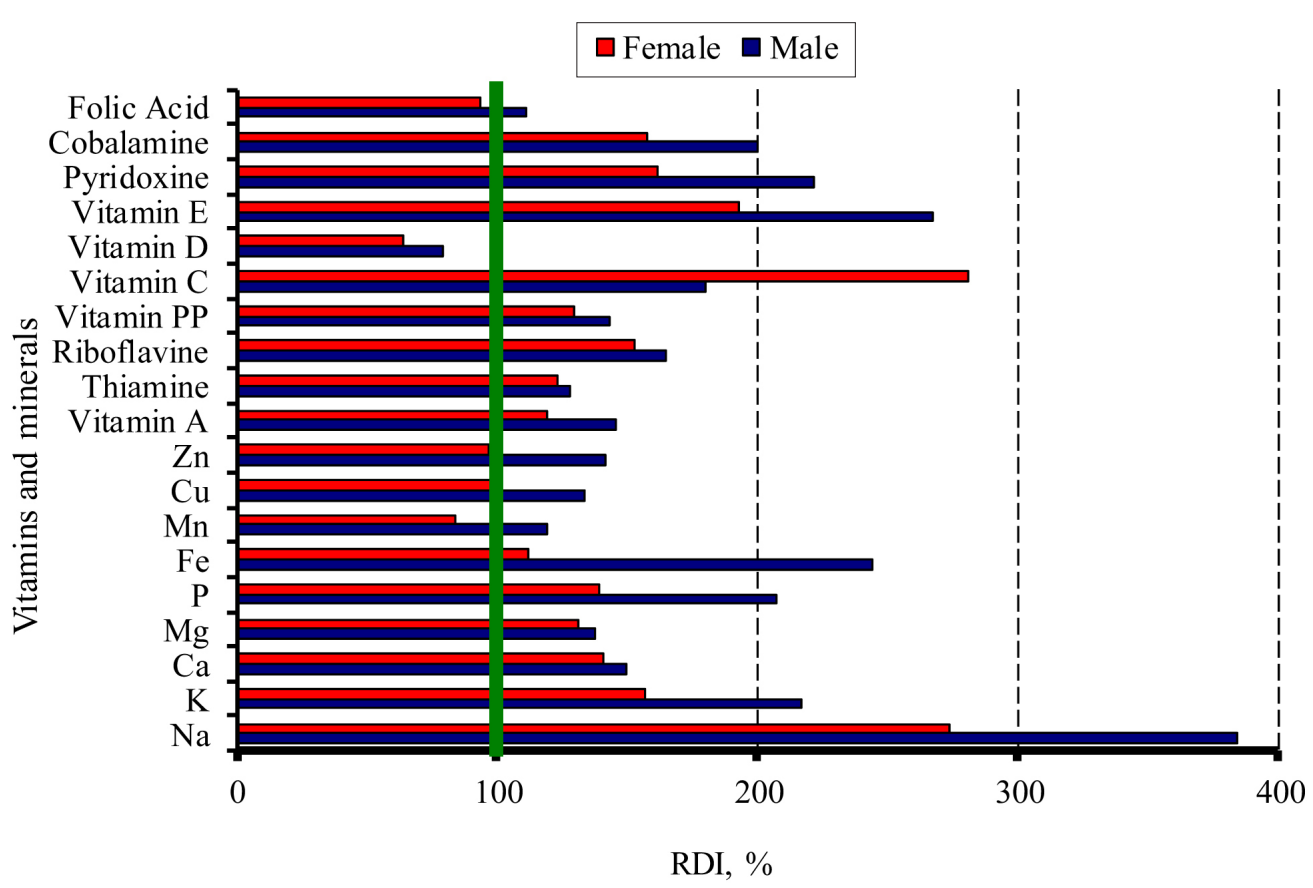

Note. Values are expressed as mean; RDI - Recommended Daily Intake; $\mathrm{Zn}$-Zinc; $\mathrm{Cu}=$ Cooper; Mn - Manganese; Fe - Iron; P - Phosphorus; $\mathrm{Mg}$ - Magnesium; Ca - Calcium; K - Potassium; Na - Sodium.

Figure 4. Correlation of muscle mass with dietary intake

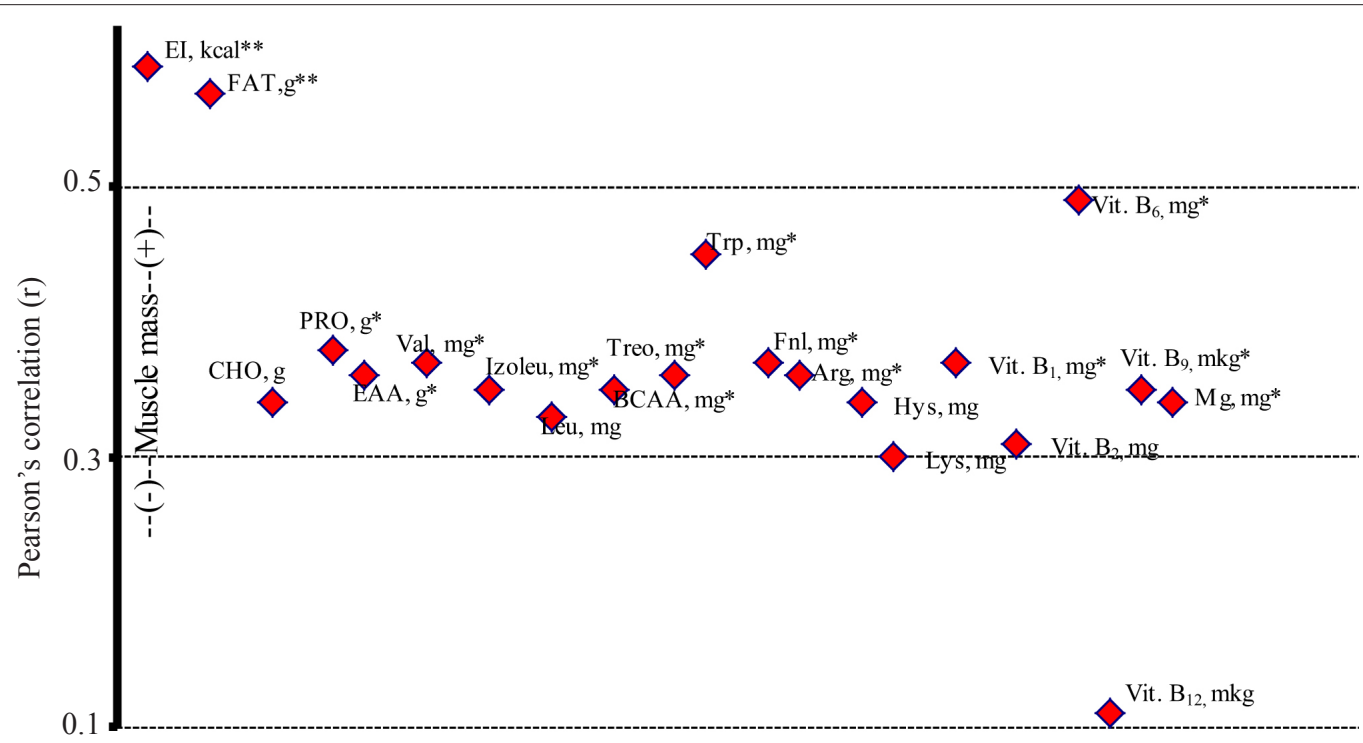

Note. Values are expressed as Pearson's correlation coefficient $(\mathrm{r}) ; *_{*} *_{-}$Correlation is significant at the 0.01 level; * ${ }_{-}$Correlation is significant at the 0.05 level; EI - Energy Intake; FAT - fat; CHO - carbohydrate; PRO - Protein; EAA - Essential Amino Acids; Val - Valine; Izole = Izoleucine; Leu - Leucine; BCAA - Branch Chain Amino Acids; Treo - Treonine; Trp - Triptofan; Fnl - Fenilalanine; Arg - Arginine; Hys - Hystidine; Lys - Lysine; Mg - Magnesium; Vit. - Vitamin. 


\section{DISCUSSION}

Aiming at achieving good results in sport, athletes' physical development, which meets the optimal requirements for elite athlete, is of great importance, and it is based on the ratio of body weight and the individual components of body weight, muscle and fat mass (MFMI). Our research results revealed differences of athletes in the aspect of gender. Too low MFMI of male athletes was determined by a relatively high fat content, and too low MFMI of female athletes was associated with too little muscle mass. It can be argued that regardless of gender, physical development of kayakers-canoeists and rowers does not completely meet the requirements of medium MFMI.

After the evaluation of athletes' diets it appeared that energy value (EI) of kayakerscanoeists and rowers dietary did not cover the full expenditure of energy. A negative EI/EER ratio was established, which could due to the fact that athletes in the dietary intake survey did not fully indicate their food and dishes, and the physical activity coefficient was estimated with errors, the chemical composition data of the dietary intake were collected of only day, the chemical composition of food intake did not include the chemical composition of food supplements. It is obvious that carbohydrates and protein food supplementation helps to maintain the optimal EI/EER ratio which provides energy. We found that $73.9 \%$ of athletes used carbohydrate supplements, and $73.9 \%$ - protein food supplements.

Rowers and canoeists-kayakers demonstrated significant biochemical changes in the body associated with characteristic energy metabolism. The main source of energy in long-term or intense physical training is carbohydrates. As a result, rowers are recommended a daily intake of sufficient amount of carbohydrates equal to $7-10 \mathrm{~g} / \mathrm{kg}$ body weight (Burke, 2010). Taking into consideration the Lithuanian Olympic team rowers' diets, we found that elite rowers and canoeists-kayakers representing Lithuania consumed too little carbohydrates and too much fat. Carbohydrate intake of our tested rowers is similar only to the previously tested athletes' intake which is less than the recommended amount of carbohydrates in Lithuania (Pečiukoniené et al., 2007), Poland (Łagowska, Jeszka, 2011) and Portugal (Teixeira et al., 2009). It is contrary to the Greek (Hassapidou, 2001), Spanish (Garcia-Rove et al., 2000), Australian (Hill, Davies, 2002), the USA (Edwards et al., 2011), New Zealand (Bond et al., 2012) athletes who use more carbohydrates (5.9-7.5 $\mathrm{g} / \mathrm{kg}$ body weight).

Intake of fat exceeding the recommended amount, when the fat supply is $35-45 \%$ of the energy value, is typical of our athletes studied. Excess fat intake (fat supply accounts for $37-40 \%$ of the energy value) was found only in Spain and earlier in Lithuania investigating the diets of kayakers-canoeists (Garciá-Rovés et al., 2000; Pečiuokonienè et al., 2007; Baranauskas et al., 2009). According to other authors, most of the kayakerscanoeists consume the recommended amount of fat (the fat supply accounts for the energy value of 26-33\%) (Garciá-Rovés et al., 2000; Hassapidou, 2001; Teixeira et al., 2009; Łagowska, Jeszka, 2011; Edwards et al., 2011; Bond et al., 2012).

It is important for athletes to consume the recommended amount of proteins. Kayakerscanoeists training their aerobic and anaerobic fitness are recommended an intake of proteins of $1.6-1.8 \mathrm{~g} / \mathrm{kg}$ body weight, and rowers developing their aerobic fitness $-1.4-1.6 \mathrm{~g} / \mathrm{kg}$ body weight (Kreider et al., 2010). Rowers and kayakerscanoeists in other countries consume more proteins than it is recommended, and more than our tested athletes.

Among the foreign rowers, the protein intake is generally $2.2-3.4 \mathrm{~g} / \mathrm{kg}$ body weight (Hassapidou 2001; Edwards et al., 2011), and for kayakerscanoeists - 2.0-2.0 g/ kg body weight (GarciaRoves et al., 2000; Teixeira et al., 2009; Bond et al., 2012). Our obtained results showed that only kayakers-canoeists used proteins following the recommendations. On the other hand, womenrowers consumed too little proteins, and men rowers - too much. Their intake of protein was $2.0 \pm 0.9 \mathrm{~g} / \mathrm{kg}$ body weight. The protein intake is recommended to enhance the muscle mass of athletes with the help of special training (Kreider et al., 2010). In Lithuania, for rowers it is important not only endurance training in the aerobic training zone, but also anaerobic alactic endurance and maximum glycolytic capacity building requiring sufficiently well-developed muscle mass (Balčiūnas, 2011). Research has shown that the specific muscle mass development is one of the factors that determine better sports results for rowers (Petkus et al., 2009).

Increasing muscle mass depends on the targeted physical activity and nutrition. Food must contain sufficient energy value, adequate protein 
and EAA (Philips, 2013). This relates to our data demonstrating that Lithuanian elite kayakerscanoeists and rowers developed their increased muscle mass consuming food with higher energy value, more fat, proteins, EAA, B vitamins $\left(\mathrm{B}_{1}, \mathrm{~B}_{6}\right.$, and folic acid) and magnesium. It was observed that athletes, particularly men, developed large muscle mass using adequate amounts of proteins, but minimum amounts of carbohydrates. Our results agree with other research evidence that protein and EAA stimulates protein synthesis independently of carbohydrate consumption (Philips, 2013). However, rowing is an endurance sport that requires an adequate carbohydrate intake. Rowers' very low carbohydrate intake slows down their adaptation to endurance physical loads (Hawley et al., 2011), possibly weakens their immune system (Gleeson et al., 2004), and they soon start to feel fatigue during training sessions (Jeukendrup, 2011). In addition, elite rowers train every day for 3-4 hours per day and carry out physical loads in high intensity training zone, so low carbohydrate intake, not fully restored glycogen stores in the muscles between practice sessions require larger efforts of the central nervous system to deal with physical loads and it is a risk factor of overtraining (Petibois et al., 2003).

Summing up, it can be argued that the dietary intake of the Lithuanian Olympic team rowers and kayakers-canoeists diet does not meet nutritional requirements of athletes. Diets of high performance kayakers-canoeists and rowers must be optimized, adjusted and individualized.

\section{CONCLUSIONS AND PERSPECTIVES}

1. Nutrition status of kayakers-canoeists and rowers does not meet the requirements: the energy intake of food does not cover the energy expenditure, the diet lacks carbohydrates, dietary fibre, omega-3 fatty acids, vitamin D, there is too much fat, saturated fatty acids and cholesterol. Female athletes' diets do not contain enough folic acid, and male athletes' diets - manganese.

2. Basic food supplements taken by kayakerscanoeists and rowers contain carbohydrates, amino acids, minerals, vitamins and multivitamins. Less commonly used dietary supplements are omega-fatty acids, creatine, caffeine and herbal supplements. Food supplementation is determined by athletes' branch of sport and gender. Kayakerscanoeists compared with rowers more often use creatine and caffeine, and female athletes compared with males more often use herbal supplements.

3. Physical development of kayakers-canoeists and rowers does not fully comply with the requirements due to medium MFMI. Regardless of the developed muscle mass, too low MFMI of male athletes is determined by relatively high fat mass. Too low MFMI of female athletes is associated with small muscle mass.

4. Better physical development of male kayakers-canoeists and rowers is linked to higher muscle mass. Athletes develop their muscle mass purposefully on their own, consuming food high in fat and protein, essential amino acids, $B$ vitamins $\left(\mathrm{B}_{1}, \mathrm{~B}_{6}, \mathrm{~B}_{9}\right)$ and magnesium. Diets of high performance kayakers-canoeists and rowers must be optimized, adjusted and individualized. In order to improve athletes' physical development and stimulate maximal adaptation of the body to physical loads during special training highprotein diet is recommended cutting down fat intake and doubling the carbohydrate intake.

\section{REFERENCES}

Ainsworth, B. E., Haskell, W. L., Herrmann, S. D. et al. (2011). Compendium of physical activities: A second update of codes and MET values. Medicine \& Science in Sports \& Exercise, 43 (1), 1575-1581.

American College of Sports Medicine, American dietetic Association, and Dieticians of Canada. Nutrition and Athletic Performance. Joint Position Statement. (2009). Medicine \& Science in Sports \& Exercise, 41, 709-731.

Balčiūnas, E. (2011). Didelio meistriškumo kanojininko rengimo ir parengtumo metiniu ciklu analizè. Sporto mokslas, 2 (64), 38-44.
Baranauskas, M., Tubelis, L., Stukas, R., Švedas, E. (2009). Lietuvos olimpinio sporto centro sportininku mitybos tyrimas. Sporto mokslas, 3 (57), 40-48.

Bond, H., Morton, L., Braakhuis, A. J. (2012). Dietary nitrate supplementation improves rowing performance in well-trained rowers. International Journal of Sports and Exercise Metabolism, 22 (4), 251-256.

Burke, L. M. (2010). Fuelling strategies to optimize performance: Training high or training low? Scandinavian Journal Medicine \& Science in Sports, 20 (2), 48-58. 
Edwards, L. M., Holloway, C. J., Murray, A. J. (2011). Endurance exercise training blunts the deleterious effect of high-fat feeding on whole-body efficiency. American Journal of Physiology - Regulatory, Integrative and Comparative Physiology, 301 (2), 320-326.

Garciá-Rovés, P., Fernández, S., Rodríguez, M. et al. (2000). Eating pattern and nutritional status of international elite flat-water paddlers. International Journal of Sport Nutrition and Exercise Metabolism, 10 (2), 182-198.

Gleeson, M., Nieman, D. C., Pedersen, B. K. (2004). Exercise, nutrition and immune function. Journal of Sports Sciences, 22, 115-125.

Harris, J., Benedict. F. (1919). A Biometric Study of Basal Metabolism in Man. Philadelphia, PA: Lippincott.

Hassapidou, M. (2001). Dietary assessment of five male sports teams in Greece. Nutrition and Food Science, 31 (1), 31-35.

Hawley, J. A., Burke, L. M., Phillips, S. M., Spriet, L. L. (2011). Nutritional modulation of training-induced skeletal muscle adaptations. Journal of Applied Physiology, 110 (3), 834-845.

Hill, R. J., Davies, P. S. (2002). Energy intake and energy expenditure in elite lightweight female rowers. Medicine \& Science in Sports \& Exercise, 34 (11), 1823-1829.

Jeukendrup, A. E. (2011). Nutrition for endurance sports: Marathon, triathlon, and road cycling. Journal of Sports Sciences, 29 (1), 91-99.

Kreider, R. B., Wilborn, C. D., Taylor, L. et al. (2010). ISSN exercise and sport nutrition review: Research and recommendations. Journal of the International Society of Sports Nutrition, 7: 7. Internet link: http://www.jissn. com/content/7/1/7.

Łagowska, K., Jeszka, J. (2011). Are young female athletes at risk of amenorrhea? An analysis of body composition and nutritional and endocrine factors. ACTA Scientiarum Polonorum - Food Science and Human Nutrition, 10 (2), 223-232.

Pečiukonienè, M., Stukas, R., Kemerytè-Riaubienė, E., Dadeliené, R. (2007). Kai kurių Lietuvos didžiausio meistriškumo sportininkų maisto racionų charakteristika. Sporto mokslas, 4 (50), 28-34.

Petibois, C., Cazorla, G., Poortmans, J. R., Déléris, G. (2003). Biochemical aspects of overtraining in endurance sports: The metabolism alteration process syndrome. Sports Medicine, 33, 83-94.

Petkus, E., Raslanas, A., Dadelienè, R., Skernevičius, J. (2009). Lietuvos olimpinès rinktinès ir olimpinès pamainos irkluotoju $2000 \mathrm{~m}$ nuotolio įveikimo laiko sąsaja su fizinio išsivystymo, fizinio ir funkcinio parengtumo rodikliais. Sporto mokslas, 3 (57), 24-29.

Phillips, S. (2013). Protein consumption and resistance exercise: Maximizing anabolic potential. Sports Science Exchange, 26 (107), 1-5.

Rekomenduojamos paros maistinių medžiagų ir energijos normos. (1999). Valstybès žinios, 102, 2936.

Skernevičius, J., Raslanas, A., Dadelienè, R. (2004). Sporto mokslo tyrimu metodologija. Fizinio išsivystymo tyrimai. Antropometrija. Vilnius: Lietuvos sporto informacijos centras. P. 51-58.

Sučilienè, S., Abaravičius, A. (2002). Maisto produktu sudetis. Vilnius: Respublikinis mitybos centras. P. 10-315.

Teixeira, V. H., Valente, H. F., Casal, S. I., Marques, A. F., Moreira, P. A. (2009). Antioxidants do not prevent postexercise peroxidation and may delay muscle recovery. Medicine \& Science in Sports \& Exercise, 41 (9), 1752-1760.

The World Health Report 2002. (2002). Reducing risks, promoting healthy life. Geneva: WHO. 